\title{
PEMBELAJARAN SENI TARI DALAM MEWUJUDKAN ASPEK PERKEMBANGAN ANAK DI TAMAN KANAK-KANAK PETERI BENSU TAKENGON
}

\author{
Eliyyil akbar \\ STAIN Gajah Putih Takengon Aceh Tengah \\ email: elayakbar@yahoo.co.id \\ Orcid ld: https://orcid.org/0000-0001-7135-9035 \\ Jainal Abidin \\ STAI Ma'arif Magetan Jawa Timur \\ email: jainal.abidin83@yahoo.com \\ Orcid ld: https://orcid.org/0000-0001-7716-4319
}

\begin{abstract}
Article received: 30 Agustus 2018, Review process: 31 Agustus 2018
Article published: 30 September 2018
\end{abstract}

\begin{abstract}
Abstrack
Discussions about children can never stop because of their unique nature. The uniqueness of children can not be responded by adults so that the pattern of education is more restraining and requires following the will of the adult mind so that it makes it difficult for children to accept and have an impact on the aspects of child development. The problem solving task is at a children's education institution by providing dance learning as a fun learning experience for children so that aspects of child development can be realized. This method uses field research with sampling or data source determination using purposive sampling. Data collection uses observation, interviews and documentation and is analyzed by means of data reduction, data display, and conclusion drawing / verification. This paper aims to review how the development of religion and morals, motor development, cognitive development, language development, social emotional development of children can be realized through dance art education. The results of this study are (1) Aspects of religious and moral development that are realized through dance can be done with movements that have behavioral indicators as applicable. If it is associated with a movement that is processed with the existence of certain objectives, it can be done by doing a movement that matches the value of goodness. (2) Aspects of motor development through dance or the beauty of a movement are seen in two parts, namely fine motor and gross motor. Fine motorization focuses the coordinate point of the hand movement by using a property in the dance while the gross motor is based on movements involving the whole body. (3) Cognitive development through dance art is seen in the aspect of children's thinking where every movement that arises in motor pressure is influenced by the results of thinking that explores the part of the brain. (4) The development of language through dance is seen in children's activities which are internalized in a word from the response of a rhythmic beauty and then responded by the whole body so that the spoken song is accompanied by a movement. (5) Child's social and emotional development can develop through dance education through a feeling produced. The ability of the child in motion is a response to the feeling in the child. This can be seen in the actualization of movements that appear with explicit themes, themes that tell about sadness or happiness make a diverse feeling. Social development cannot be separated from the interaction between dancers and viewers and between the dancers.
\end{abstract}

Keyword: Dance education, child development 


\begin{abstract}
Abstrak
Pembahasan mengenai anak tidak pernah dapat berhenti karena sifatnya yang unik. Keunikan anak kurang dapat direspon oleh orang dewasa sehingga pola edukasi lebih bersifat mengekang dan mengharuskan mengikuti kemauan jalan pikiran orang dewasa sehingga menjadikan anak sulit menerima dan berdampak pada ketidakoptimalan aspek perkembangan anak. Tugas problem solving berada pada sebuah lembaga pendidikan anak dengan memberikan pembelajaran seni tari sebagai pengalaman belajar yang menyenangkan kepada anak sehingga aspek perkembangan anak dapat terwujud. Metode ini menggunakan field research dengan pengambilan sampel atau penentuan sumber data menggunakan purposive sampling. Pengumpulan data menggunakan observasi, wawancara dan dokumentasi dan dianalisis dengan cara data reduction, data display, dan conclusion drawing/verification. Tulisan ini bertujuan untuk mengulas bagaimana perkembangan agama dan moral, perkembangan motorik, perkembangan kognitif, perkembangan bahasa, perkembangan sosial emosional anak dapat terwujud melalui pendidikan seni tari. Hasil kajian ini adalah (1) Aspek perkembangan agama dan moral yang diwujudkan melalui seni tari dapat dilakukan dengan gerakan yang terdapat indikator perilaku sesua norma yang berlaku. Jika dikaitkan dengan suatu gerakan yang diolah dengan adanya unsur tujuan tertentu dapat dilakukan dengan melakukan gerakan yang sesuai nilai kebaikan. (2) Aspek perkembangan motorik melalui seni tari atau keindahan suatu gerakan terlihat pada dua bagian yaitu motorik halus dan motorik kasar. Motorik halus memfokuskan titik kordinat gerakan tangan dengan menggunakan suatu properti dalam tarian sedangkan motorik kasar bertumpu pada gerakan yang melibatkan seluruh tubuh. (3) Perkembangan kognitif melalui seni tari terlihat pada aspek olah pikir anak yang mana setiap gerakan yang muncul pada tekanan motorik dipengaruhi oleh hasil pemikiran yang menjelajah pada bagian otak. (4) Perkembangan bahasa melalui seni tari terlihat pada aktifitas anak yang diinternalisasikan pada suatu kata-kata dari respon sebuah keindahan irama kemudian direspon oleh seluruh tubuh sehingga antara lagu yang terucap disertai dengan suatu gerakan. (5) Perkembangan sosial emosional anak dapat berkembang melalui pendidikan seni tari nampak melalui sebuah perasaan yang dihasilkan. Kemampuan anak dalam gerak merupakan respon dari rasa yang terdapat dalam diri anak. Hal tersebut terlihat pada aktualisasi gerakan yang muncul dengan tema yang tersurat, tema yang menceritakan tentang kesedihan atau kebahagiaan menjadikan sebuah perasaan yang beragam. Perkembangan sosial tidak terlepas dari interaksi antar penari dan penonton dan antar penari itu sendiri.
\end{abstract}

Kata kunci: Pendidikan seni tari, perkembangan anak

\title{
PENDAHULUAN
}

Perkembangan anak usia dini merupakan hal yang menjadi perhatian khusus karena perkembangan dapat menentukan proses pembelajaran ke jenjang selanjutnya. Selain itu dapat dikatakan sebagai proses tahapan pertumbuhan ke arah yang lebih maju. Perkembangan melibatkan proses perubahan kualitatif yang mengacu pada mutu fungsi-fungsi organ jasmaniah. Mussen yang dikutip Baharudin menyatakan bahwa perkembangan merupakan suatu perubahan yang terjadi pada manusia atau hewan di antara konsepsi sampai meninggal dunia (Baharudin: 2010: 69). Istilah perkembangan secara khusus diartikan sebagai 
perubahan-perubahan yang bersifat kualitatif dan kuantitatif yang menyangkut aspek-aspek mental psikologis manusia. Perkembangan yang dimaksud adalah proses tertentu yaitu proses yang terus menerus, dan proses yang menuju ke depan dan tidak begitu saja dapat diulang kembali.

Tidak sedikit yang mengatakan bahwa perkembangan anak sebaiknya distimulasi sejak masa keemasan. Sebagaimana yang dijelaskan dalam teori Montessori bahwa anak usia dini cenderung lebih cepat menyerap ilmu jika dibandingkan dengan usia-usia sesudahnya (LesleyBritton: 1992: 12). Senada dengan ungkapan Montessori, belajar melalui kebiasaan dalam melakukan hal-hal yang bermakna menjadikan anak semakin cakap dalam melakukan kegiatan tersebut. Rentang Usia emas terdapat pada masa 0-6 tahun, sebagaimana yang disampaikan oleh Syaodih bahwa kecerdasan manusia dapat tercapai 50\% ketika umur 4 tahun, sedangkan usia 8 tahun mencapai $80 \%$, usia 18 tahun mencapai titik kulminasi. Sehingga usia emas dapat terjadi pergerakan pesat dalam hal perkembangan fisik maupun psikis. Sangat disayangkan jika masa tersebut disia-siakan karena kemampuan yang dimiliki anak dapat berkembang maksimal pada usia-usia tepat dengan cara pengembangan secara maksimal sehingga dapat menjadi bekal persiapan pada kehidupan yang akan mendatang.

Fenomena saat ini baik dari pihak orang tua maupun pendidik, tidak sedikit yang memberikan anak pengertian, pemahaman atau mengajarkan anak sesuai dengan jalan pikiran orang dewasa sehingga akibatnya anak sulit menerima. Hal tersebut menjadi bukti bahwa jalan pikiran orang dewasa tidak sama dengan jalan pikiran anak Nurvitasari, 2016: 96). Bahkan Sahabat Rasul, Ali Bin Abi Thalib memberi nasehat "Didiklah anak-anakmu untuk menghadapi zamannya dan jangan engkau didik sesuai zamanmu, mereka adalah anak-anak di zamannya dan bukan anak-anak kehidupan zamanmu, bila seorang anak engkau didik untuk mengikuti zamanmu, maka ia akan tertinggal di zamannya (Watiniyah, 2015: 9). Kenyataan yang ada, pola pendidikan anak usia dini yang dberikan oleh orang yang lebih tua bersifat pengekangan dan menonjolkan bukan kemampuan anak. Padahal anak masih membutuhkan keriangan bermain sehingga seluruh potensi yang dimiliki anak dapat berkembang. Kreativitas anak dapat melejit melalui imajinasi jika tidak banyak intruksi "larangan" dari orang dewasa. Bentuk pembunuhan kreativitas anak yang banyak terjadi adalah adanya pengawasan yang berlebihan, evaluasi yang terlalu ketat, hadiah yang terlalu banyak, kompetisi yang terlalu sengit, kontrol yang sangat ketat, membatasi pilihan anak dan 
harapan di luar kemampuan (Rahman: 2019, 47). Pembatasan kreatifitas anak menyebabkan terhambatnya pertumbuhan dan perkembangan anak itu sendiri.

Pengembangan aspek perkembangan anak diperlukan peran lembaga pendidikan dalam hal ini adalah pendidikan anak usia dini atau Taman Kanak-Kanak karena dengan adanya pendidikan anak usia dini berarti membantu program pemerintah dalam mencerdaskan anak bangsa. Aspek perkembangan anak meliputi perkembangan agama dan moral, perkembangan motorik, perkembangan kognitif, perkembangan bahasa, perkembangan sosial emosional. Sebuah lembaga pendidikan perlu memberikan stimulasi secara holistik dalam mengoptimalkan perkembangan anak dengan satu cara seribu makna yakni melalui pendidikan seni tari. Seperti yang dijelaskan oleh Zulkifli bahwa gerakan yang sering dilakukan anak terdapat tiga jenis yaitu motorik statis yang merupakan gerakan tubuh untuk memperoleh keseimbangan gerak ketika berjalan, kedua motorik ketangkasan yang bertujuan untuk mewujudkan ketangkasan dan keterampilan, ketiga motorik penguasaan yang bertujuan untuk mengendalikan otot tubuh sehingga ekspresi muka dapat terlihat (Kusumastuti: tt, 3). Oleh karenanya esensi tari yaitu gerak dapat mengakomodir aspek olah tubuh, olah pikir serta olah emosi yang dapat mendukung komponen perkembangan anak.

Pembelajaran tari pada anak usia dini merupakan sarana media dalam meningkatkan perkembangan anak yang meliputi perkembangan kognitif, motorik, sosial emosional dan aspek perkembangan lainnya. Pembelajaran tari dapat memberikan pengalaman belajar yang menyenangkan kepada anak baik dalam kelompok besar ataupun yang terkecil. Anak usia dini mempunyai karakteristik yang unik oleh karenanya pola pengembangan tari tentu berbeda dengan anak-anak yang beralih pada tingkat dasar. Pola pengembangan tari yaitu dilakukan secara holistik (menyeluruh), artinya antara gerak, irama dan ekspresi dilakukan secara bersamaan. Banyak anggapan yang mengatakan bahwa tari bukan merupakan kunci kesuksesan karena para orang tua lebih cenderung menyekolahkan anak-anak yang bertujuan mempelajari sains, matematika, bahasa asing karena penting untuk bekal kehidupan mendatang. Aktualisasi tari untuk anak-anak berbeda dengan tari yang dilakukan oleh orang dewasa karena karakter fisik dan mental yang berbeda.

Dengan belajar tari dapat memperoleh hasil yang optimal terkait seluruh aspek perkembangan anak sehingga mengalahkan hasil akademis karena dapat terus melekat sampai anak beranjak dewasa. Dengan belajar tari bukan bertujuan untuk menjadikan anak sebagai 
penari. Sebagaimana pembelajaran pada Taman Kanak-Kanak Peteri Bensu, setiap hari terdapat pembiasaan gerak yang merupakan esensi dari seni tari, setiap pembelajaran melibatkan seni tari dalam mengembangkan aspek perkembangan anak. Oleh karena itu tulisan ini mengulas bagaimana perkembangan agama dan moral, perkembangan motorik, perkembangan kognitif, perkembangan bahasa, perkembangan sosial emosional anak dapat berkembang melalui pendidikan seni tari. Sehingga seni tari dapat menjadi pembelajaran holistik dalam mengembangkan aspek perkembangan anak dan masa anak dapat dilalui dengan optimal karena jika salah satu aspek perkembangan anak tidak optimal maka dapat memberi dampak pada kehidupan anak masa yang akan datang. Pisau analisis dalam kajian ini fokus pada pembelajaran seni tari dan aspek perkembangan anak.

\section{PEMBELAJARAN SENI TARI}

Istilah pembelajaran berasal dari kata belajar yaitu aktivitas untuk memperoleh pengetahuan, meningkatkan keterampilan, memperbaiki perilaku, sikap dan mengukuhkan kepribadian. Maksud dari pengertian ini lebih menunjukkan pada perubahan individu, baik ilmu pengetahuan, sikap dan kepribadian. Rusman mengutip pendapat Surya mengatakan bahwa pembelajaran merupakan proses yang dilakukan individu untuk memperoleh perubahan perilaku yang baru secara keseluruhan, sebagai pengalaman individu dalam interaksi dengan lingkungan (Rusman: 2011, 116). Menurut Hamzah, pembelajaran merupakan kegiatan yang mengupayakan membelajarkan siswa secara integrasi dengan memperhitungkan faktor lingkungan belajar, karakteristik anak (Uno, 2009: V). Lingkungan belajar dapat mempengaruhi suasana belajar anak sehingga penekanan ini lebih dipertajam. Pembelajaran merupakan kegiatan atau aktivitas untuk mendapatkan pengetahuan yang akan menjadikan perubahan sikap atau perilaku dan pengetahuan tersebut disesuaikan dengan karakteristik anak. Fokus pembelajaran dalam hal ini adalah terkait pembelajaran seni.

Seni tumbuh dan berkembang sejajar dengan perkembangan manusia, tidak ada yang tahu secara pasti kapan seni mulai dikenal manusia. Seni berasal dari kata techne yang mempunyai arti pekerjaan yang berguna dan berfaidah (Supangkat, 2005:107). Dalam memaknai seni dari masa ke masa akan menjadikan pandangan yang berbeda-beda. Ungkapan seni pada masa lampau merupakan kemampuan dalam menghadapi kesulitan serta sabar dalam melakukan suatu pekerjaan. Sedangkan pada masa kini yang dimaksud dengan seni adalah keindahan (artistik) yang cenderung kepada hal-hal yang indah (Allam, 2005: 107). 
Seni merupakan sesuatu yang indah dihasilkan oleh manusia dan penghayatan manusia melalui penglihatan, pendengaran dan perasaan. Seni merupakan penjelmaan rasa indah yang terkandung jiwa seseorang. Sebagaimana sabda Rasulullah yang diriwayatkan Muslim bahwa Allah itu indah dan menyukai keindahan (Hadzami, 2010: 213). Terkait keindahan seni, Imam Ghazali mengatakan bahwa mendengar nada yang indah dapat membangkitkan hal (penghayatan yang datang dalam hati (jiwa) tanpa kesengajaan dan tidak diupayakan yang merupakan anugerah Allah) dalam kalbu yang disebut al-wujd (Qushayri, t.th: 57). Beliau memperbolehkan mendengar musik dan lagu dengan ungkapan: "Barang siapa yang tidak terkesan hatinya di musim bunga dengan kembang-kembangnya atau oleh musik dan getaran nadanya maka fitrahnya telah mengidap penyakit parah yang sulit diobati (Al-Ghazali, t.th: 1131). Jadi seni merupakan keindahan yang merupakan ekspresi ruh dan budaya manusia yang mengandung dan mengungkapkan keindahan. Hal tersebut merupakan anugerah yang diberikan Allah kepada hambanya, oleh karena itu dengan seni orang dapat memperoleh kenikmatan sebagai akibat timbal balik perasaan terhadap stimulus yang dirasakan. Kenikmatan seni hanya bisa dirasakan oleh batin, karena timbul atau muncul ketika orang dapat menangkap dan merasakan simbol-simbol estetika dari pencipta seni, maka seni lebih dikenal dengan nilai spiritual.

Pada dasarnya seni dibedakan atas seni sastra atau kesustraan yang merupakan seni dengan alat bantu bahasa seperti puisi, cerpen, pantun, dan lainnya; seni musik yang merupakan seni dengan alat bunyi atau suara meliputi musik klasik, jazz, pop, bosa, rock dan musik tradisional; seni tari yang merupakan seni dengan alat gerakan yang meliputi tari klasik, tari kreasi baru, tari tradisional, tari modern; seni rupa yang merupakan seni dengan alat garis, bentuk, warna dan lainnya. Seni rupa ini dibagi menjadi dua yaitu seni rupa murni dan seni rupa terapan. Seni rupa murni merupakan seni yang diciptakan tanpa mempertimbangkan kegunaannya atau seni bebas. Sedangkan seni rupa terapan meliputi seni lukis, seni kriya, seni patung, seni dekorasi dan seni reklame; Seni drama atau teater yang merupakan seni dengan kombinasi sastra musik, tari dan rupa meliputi teater lama, teater komedi, teater baru dan sendratasik (seni drama tari dan musik). Dari penjelasan mengenai macam-macam seni, dalam uraian kajian ini hanya berfokus pada seni tari (Anshari, 1992: 141). Tari adalah serangkaian gerakan yang dilakukan ke dalam pola dan mengatur iringan (Grau, 2005: 8). Setiap masyarakat mempunyai praktek tari yang mungkin tampil dengan 
solo, pasangan atau kelompok. Menurut Soedarsono tari merupakan gerak dari seluruh anggota tubuh manusia yang disusun secara selaras dengan irama musik serta mempunyai maksud tertentu (Soedarsono, 1992: 81). Ungkapan tari dalam perkembangan anak pada hakikatnya adalah gerak. Gerakan yang dilakukan anak akan berbeda dengan gerakan orang dewasa karena gerakan anak mengalami proses dari yang mudah sampai kepada gerakan yang lebih rumit. Perkembangan gerak anak usia dini dapat diukur berdasarkan kategori ke dalam beberapa fase perkembangan psikomotorik. Karakteristik gerak motorik pada anak terdiri dari dua gerakan yaitu gerakan motorik halus dan gerakan motorik kasar (Neaum, 2010: 48).

Tari pada anak berfungsi sebagai media ekspresi, media komunikasi, media bermain serta pengembangan bakat dan media kreatifitas. Adapun Jenis-jenis tari pada anak yaitu tari yang disesuaikan dengan gerak motorik anak; bentuk tari sebaiknya memperhatikan karakteristik gerak anak seperti gerak menirukan, gerak manipulasi (perlakuan) spontan, gerak bersahaja (melakukan dengan sederhana dan apa adanya); fungsi tari bukan sebagai media upacara, hiburan atau tontonan, namun sebagai media kreatifitas; tema pada tari disesuaikan dengan perkembangan psikologi anak. Selain itu, Kusmawardani yang dikutip Rachmi menjelaskan bahwa jenis-jenis tari pada anak (Rachmi, 2010: 6.24-6.25) pertama tari yang bertema yaitu disesuaikan dengan pembelajaran yang diberikan pada anak, tujuannya memberi kesempatan untuk mengungkapkan pengetahuan dan pengalaman terhadap sesuatu yang dilihat, didengar dan dirasakan melalui panca indera. Tari bertema merupakan gerakan yang berdasarkan tema pada suatu pembelajaran. Kedua gerak tari bersifat tiruan (gerak imitatif) yaitu dilakukan dengan menirukan perilaku manusia, menirukan kegiatan kerja, gerakan binatang, gerak benda, gerak alam misalnya marah, sedih, burung, pohon tertiup angin, hujan, angin. Tujuannya untuk memberi kesempatan menampilkan situasi kehidupan nyata berdasarkan kemampuan memahami hal yang dilihat, dirasakan. Untuk mengeksplorasi sesuatu yang dikenalnya tentang lingkungan dan diri anak. Ketiga gerak tari yang variatif yaitu gerak anak yang terdiri dari jenis gerak yang variatif tujuannya memberi kesempatan anak untuk memperlihatkan pengendalian otot di seluruh tubuh. Keempat, berbentuk tari kelompok. Tujuannya mengembangkan kebutuhan sosialnya, dengan cara itu anak mendapatkan cara yang positif dalam berhubungan dengan orang lain sehingga tercipta sikap toleransi sesamanya. Kelima, pola lantai kurang lebih lima, sebab kemampuan anak untuk konsentrasi dan menghafal urutan pola lantai terbatas yang bertujuan pola lantai memberi 
kesempatan bergerak sambil melakukan perubahan posisi tempat menari dan perubahan arah. Pola lantai yang dimaksud adalah pola gerak atau variasi dalam menari. Keenam, lama waktu menari kurang lebih 5 menit yang tujuannya memberi kesempatan anak untuk menunjukkan kemampuannya berkonsentrasi dan perhatian lebih lama. Keenam, diiringi oleh musik yang bertujuan agar lebih menarik dan merangsang anak untuk lebih semangat melakukan gerak. Dari penjelasan jenis tari untuk anak usia dini tersebut, dapat dipahami bahwa tari untuk anak mempunyai kategori yaitu kegiatan yang melibatkan seluruh anggota badan dan didesain untuk mengembangkan potensi anak dan meningkatkan tumbuh kembang anak. Tari untuk anak disesuaikan dengan usia, karena setiap usia menentukan perkembangan yang dicapai.

Pembelajaran seni tari merupakan kegiatan atau aktivitas untuk mendapatkan pengetahuan yang akan menjadikan perubahan sikap atau perilaku dan pengetahuan tersebut disesuaikan dengan karakteristik anak melalui keindahan yang dihasilkan oleh pendidik atau peserta didik melalui penglihatan, pendengaran dan perasaan dengan gerak-gerakan dari seluruh anggota tubuh manusia yang disusun secara selaras dengan irama musik serta mempunyai maksud tertentu. Pembelajaran seni tari anak usia dini merupakan kegiatan perubahan sikap atau perilaku melalui tari. Pelaksanaan pembelajaran seni tari di lembaga PAUD, pengalaman belajar tari disebut sebagai pembelajaran. Pada pendidikan anak usia dini kompetensi keterampilan lebih fokus dalam melatih motorik, bukan menjadikan anak mahir atau ahli. Pembelajaran tari pada anak usia dini merupakan sarana media dalam meningkatkan perkembangan anak yang meliputi perkembangan kognitif, motorik, sosial emosional dan aspek perkembangan lainnya. Pembelajaran tari dapat memberikan pengalaman belajar yang menyenangkan kepada anak baik dalam kelompok besar ataupun yang terkecil.

\section{ASPEK PERKEMBANGAN ANAK}

Aspek perkembangan anak meliputi Pertama, perkembangan agama dan moral. Aspek perkembangan nilai-nilai agama dan moral merupakan hal yang paling mendasar dan akan menjadi fondasi bagi kehidupan anak pada masa dewasannya. Kemampuan ini bertujuan untuk melatih anak melalui pembiasaan ibadah dengan cara yang menyenangkan, mengenal, dan mencintai Tuhan sejak dini sehingga akan terwujud perilaku akhlaqul karimah, ikhlas, sabar, jujur, dan senang menjalankan perintah Agama. Dahulu orang menganggap bahwa anak perlu diajarkan apa yang "benar" dan apa yang "salah". Dalam penelitian selanjutnya, perkembangan moral merupakan proses yang lebih kompleks yang melibatkan pertumbuhan 
sosial dan penalaran intelektual. Perilaku moral merupakan perilaku yang sesuai dengan standar moral dari kelompok sosial tertentu. Perilaku moral terbentuk dari perilaku yang menjadi kebiasaan bagi anggota masyarakat.

Kedua, perkembangan motorik. Perkembangan motorik merupakan studi tentang perubahan perilaku motorik dari waktu ke waktu. Perkembangan motorik ini dibedakan menjadi dua yaitu perkembangan motorik kasar dan motorik halus. Perkembangan motorik kasar berhubungan dengan gerakan dasar yang terkoordinasi dengan otak seperti berlari, berjalan, melompat, memukul dan menarik. Sedangkan motorik halus berfungsi melakukan gerakan yang lebih spesifik seperti melipat, menggunting, mengancingkan baju dan mengikat tali sepatu. Anak usia lima tahun memiliki banyak tenaga seperti anak usia empat tahun, namun keterampilan gerak motorik halus maupun kasar sudah terarah dan terfokus pada tindakan mereka. Keterampilan gerak motorik menjadi lebih diperhalus dan keterampilan gerak motorik kasar menjadi lebih gesit dan serasi. Dari konsep perkembangan fisik motorik yang dijelaskan tersebut dapat diketahui bahwa anak memiliki tenaga untuk melakukan kegiatan dan umumnya mereka sangat aktif dan mampu melakukan gerakan yang terkordinasi.

Ketiga, perkembangan kognitif. Pada lingkup pengembangan ini, kemampuan yang ingin dicapai adalah kemampuan berpikir logis, kritis, memberi alasan, memecahkan masalah, dan menemukan hubungan sebab akibat. Kemampuan tersebut dapat dicapai secara baik jika anak dilatih sejak usia dini. Perkembangan kognitif merupakan proses mental yang mencakup pemahaman mengenai dunia, penemuan pengetahuan, pembuatan perbandingan, berfikir dan mengerti. Proses mental yang dimaksud adalah proses pengolahan informasi yang menjangkau kegiatan kognisi, intelegensi, belajar, pemecahan masalah dan pembentukan konsep. Perkembangan ini berkaitan dengan pembangunan proses berfikir, yang mana prosesnya dari memperoleh, mengatur dan menggunakan apa yang dipelajari (Neaum, 2010: 48). Santrock menyatakan bahwa tahap pra-operasional, anak mulai merepresentasikan dunianya dengan kata-kata, bayangan dan gambar (Santrock, 2007: 251). Anak mulai aktif berfikir simbolik, pemikiran mental muncul, egosentrisme tumbuh dan keyakinan mulai terkonstruksi. Pada tahap pra-operasional dibagi menjadi dua sub tahap, yaitu sub tahap fungsi simbolik yang terjadi antara usia 2 sampai 4 tahun. Pada tahap ini anak menggambarkan secara mental sebuah objek yang tidak ada menjadikan kemampuan anak 
lebih meluaskan dunia mereka. Pada tahap ini anak mulai menggunakan bahasa dan melakukan permainan "pura-pura" walaupun masih berfikir egosentris. Sub tahap yang kedua adalah sub tahap pemikiran intuitif yang terjadi antara usia 4-7 tahun. Pada tahap ini anak mulai mempraktikkan penalaran primitif dan ingin mengetahui jawaban dari pertanyaanpertanyaan, cara berfikirnya masih irreversible (tidak dapat dibalik). Anak belum mampu meniadakan suatu tindakan dari arah sebaliknya. Dari penjelasan tersebut dapat diketahui bahwa unsur anak yang menonjol pada tahap pra-operasional adalah mulai digunakannya bahasa simbolis yang berupa gambaran dan bahasa ucapan. Dengan bahasa anak dapat mengenal bermacam benda dan mengetahui nama benda yang dikenal melalui pendengaran dan penglihatan. Perkembangan bahasa akan memperlancar perkembangan kognitif anak.

Keempat, perkembangan bahasa. Bahasa memiliki peranan yang sangat penting dalam kehidupan sehari-hari di antaranya sebagai sarana berfikir, sarana mendengarkan, sarana berbicara dan sarana agar anak mampu membaca dan menulis. Bahasa merupakan cara utama di mana kita berfikir dan berkomunikasi (Neaum, 2010: 49). Melalui bahasa seseorang dapat menyampaikan keinginan dan pendapatnya kepada orang lain. Perkembangan bahasa dipengaruhi oleh lingkungan atau interaksi sosial dengan orang dewasa dan penguasaan bahasa pada manusia tidak dipengaruhi semata-mata oleh proses belajar tetapi yang lebih penting dari itu ialah dipengaruhi oleh biological predisposition yakni kecenderungan biologis yang dibawa sejak lahir (Muhibin, 1995: 43). Kemampuan bahasa berkaitan erat dengan kemampuan kognitif anak, walaupun bahasa dan pikiran merupakan dua aspek yang berbeda. Namun sejalan dengan perkembangan kognitif anak, bahasa menjadi ungkapan dari pikiran.

Kelima, perkembangan sosial, emosional. Perkembangan sosial merupakan kemampuan pertumbuhan anak untuk berhubungan dengan orang lain secara tepat dalam kehidupan (Muhibin, 1995: 4). Perkembangan sosial dimulai sejak dini dengan munculnya senyuman sosial. Reaksi sosial pertama pada bayi yang ditujukan pada orang tuanya. Kemudian pada orang lain di lingkungannya. Pola perilaku sosial yang dibina pada masa tersebut merupakan landasan bagi perkembangan sosial berikutnya. Masa kanak-kanak awal anak belajar menyesuaikan diri dengan kelompok teman sebaya dan mengembangkan pola perilaku yang sesuai dengan harapan sosial. Perkembangan sosial berarti perolehan kemampuan berperilaku yang sesuai dengan tuntutan sosial. Emosi merupakan perasaan atau 
afeksi yang melibatkan perpaduan antara gejolak fisiologis dan gejala perilaku yang telihat. Perkembangan emosi adalah kemampuan pertumbuhan anak untuk merasakan dan mengungkapkan gejolak dan gejala yang terlihat secara tepat (Neaum, 2010: 54). Dampak perkembangan emosi adalah menambah rasa nikmat bagi pengalaman sehari-hari, emosi menyiapkan tubuh untuk melakukan tindakan, emosi merupakan suatu bentuk komunikasi, emosi mengganggu aktivitas mental dan reaksi emosi yang diulang akan menjadi kebiasaan.

\section{METODOLOGI}

Jenis penelitian ini menggunakan penelitian lapangan (field research). Dengan penelitian lapangan aspek perkembangan agama dan moral, perkembangan motorik, perkembangan kognitif, perkembangan bahasa, perkembangan sosial emosional anak dapat terwujud melalui pendidikan seni tari dapat terungkap. Penelitian lapangan dilakukan karena peneliti terjun langsung ke lapangan dan ikut terlibat (Raco, 2010: 9). Lokasi penelitian ini dilakukan di lembaga pendidikan anak usia dini yaitu Taman Kanak-Kanak Peteri Bensu. Dalam penelitian ini peneliti menentukan informan sebagai sumber utama. Sumber data yang penulis gunakan mengacu kepada apa yang dikemukakan Sugiyono, pengambilan sampel atau penentuan sumber data dalam penelitian kualitatif adalah menggunakan purposive sampling. Artinya, penentuan sumber datanya dengan pertimbangan tertentu (Sugiyono, 2010: 300). Sumber data penulis adalah kepala sekolah, guru. Untuk mengumpulkan data terkait aspek perkembangan agama dan moral, perkembangan motorik, perkembangan kognitif, perkembangan bahasa, perkembangan sosial emosional anak dapat terwujud melalui pendidikan seni tari dilakukan dengan observasi, wawancara dan dokumentasi. Observasi tersebut penulis gunakan untuk mengamati dan mencatat perilaku sumber data. Seperti yang diungkap oleh Endang bahwa observasi merupakan metode pengumpulan data melalui pengamatan dan pencatatan perilaku subjek penelitian yang dilakukan secara sistematik (Mulyatiningsih, 2011, 26). Ketika observasi penulis menggunakan penggabungan dari overt (terang-terangan) yaitu dengan menyatakan kepada kepala sekolah, guru bahwa penulis melakukan riset tentang aspek perkembangan agama dan moral, perkembangan motorik, perkembangan kognitif, perkembangan bahasa, perkembangan sosial emosional anak dapat terwujud melalui pendidikan seni tari dan covert (samar-samar) yaitu untuk menghindari keberadaan data yang tersembunyi, karena bisa jadi data tersebut menjadi data yang paling 
penting dengan keikutsertaan penulis mendampingi anak usia dini dalam penerapan pendidikan seni tari. Pada tahap wawancara, penulis menggunakan wawancara semistruktur yaitu melakukan wawancara mendalam (in-depth interview). Penulis mewawancarai para sumber dengan terbuka dan mendapatkan ide dari para sumber. Hasil wawancara tersebut penulis amati secara teliti dan mencatat hasil dalam catatan. Pada tahap dokumentasi, penulis melakukan dokumentasi dengan berbentuk tulisan yang meliputi RPPT, RPPS, RPPH, kurikulum, catatan kegiatan atau event yang melibatkan anak dalam pelaksanaan pendidikan seni tari. Sedangkan dokumentasi berbentuk gambar meliputi foto kegiatan implementasi pendidikan seni tari. Melalui metode dokumentasi, penulis memperoleh data-data penting seperti deskripsi tentang tema penelitian, uraian pendukung obyek penelitian. Dalam menganalisis data penelitian ini, penulis menggunakan model Miles dan Huberman selama berada di lapangan. Aktivitas dalam analisis data meliputi data reduction, data display, dan conclusion drawing/verification.

\section{HASIL DAN PEMBAHASAN}

Pembelajaran seni tari pada Taman Kanak-Kanak Peteri Bensu Takengon dilakukan setiap hari karena seperti yang dijelaskan bahwa tiada hari tanpa gerak. Hal tersebut dikuatkan bahwa setiap seni pasti mempunyai unsur estetis di dalamnya. Unsur estetis seni dapat melibatkan medium di dalamnya. Medium seni tari merupakan gerak. Sebagaimana yang dijelaskan pada pembahasan di atas bahwa tari yang dilakukan anak usia dengan orang dewasa tentu mempunyai perbedaan yang signifikan. Tari pada anak bertujuan untuk membiasakan dalam mewujudkan tingkah laku. Seni tari merupakan hasil karya cipta manusia yang diungkapkan melalui media gerak yang memiliki keindahan (Dewi, 2012: 1). Bentuk keindahan untuk anak adalah adanya rasa kepuasan, kebahagiaan dan harapan (Astuti, 2016: 21). Tujuan gerak bagi anak yaitu untuk menyampaikan pesan realita hidup yang bisa dirasakan pelaku gerak. Dengan gerakan atau tari dapat memberi pengalaman yang bermakna dalam rangka membangun dan memperkaya pengalaman batin. Pada dasarnya, tari yang disajikan pada Taman Kanak-Kanak Peteri Bensu mempunyai maksud dan tujuan salah satunya untuk sarana pendidikan dan hiburan. Gerak yang dilakukan anak terdapat berbagai macam bentuk sesuai yang diarahkan pendidik. Sebagaimana karakteristik gerak yang biasa dilakukan anak adalah meniru, manipulasi, dan bersahaja (Rachmi, 2010: 6.7-6.8). Dalam 
aktivitas bermain di Taman Kanak-Kanak Peteri Bensu, anak cenderung menirukan hal-hal yang diamati baik secara audio, visual maupun audio visual. Seperti anak melihat pesawat terbang, gaya menirukan gerakan tersebut dengan berlari sambil mengangkat kedua tangan dengan bersuara layaknya pesawat. Sama halnya ketika kegiatan pembelajaran di kelas, anak memberikan visualisasi gerakan sesuai dengan tema. Gerakan manipulasi pada Taman KanakKanak Peteri Bensu adalah anak melakukan gerakan secara spontan menurut objek yang diamati dan sesuai dengan keinginannya. Misalnya, anak diminta melakukan gerakan harimau, secara spontan anak akan melompat sesuai keinginannya dan mengaum-ngaum yang seolah-olah membayangkan seperti gerakan harimau. Aktivitas yang dilakukan dengan sederhana tanpa unsur kesengajaan atau bersahaja seperti yang dilakukan anak Taman KanakKanak Peteri Bensu saat penyambutan kedatangan anak-anak, didengarkan alunin musik anak-anak, maka saat suara musik terdengar oleh anak maka akan menggerakkan bagian tubuhnya sesuai keinginannya. Dengan adanya karakteristik gerak pada anak, seorang guru dapat mengembangkan sebagai gerak berirama atau tari.

Pembelajaran tari anak usia dini berarti mengembangkan berbagai ragam ranah belajar. Kegunaan pembelajaran tari anak mencakup kegunaan kognitif, kegunaan afektif, fisik dan sosial. Pembelajaran tari selain hanya nampak pada kegiatan fisik motorik sebaiknya juga memperhatikan aspek perkembangan anak yang lainnya seperti kognitif, sosial, emosional, moral dan lainnya. Sehingga dalam kegiatan tari dapat dilakukan secara terpadu dalam mengembangkan aspek perkembangan anak. Kegiatan tari pada anak usia dini mencakup aspek eksplorasi, improvisasi, inkubasi, evaluasi dan hasil atau komposisi tari(Rachmi, 2010: 10.23-10.28). Kegiatan eksplorasi yang dilakukan oleh Taman KanakKanak Peteri Bensu yaitu melakukan pengumpulan berbagai macam gerakan yang kemudian diajarkan kepada anak dengan cara. Dalam pembelajaran mencari gerakan biasanya ditentukan oleh tema. Namun tema bukan menjadi acuan pokok dalam eksplorasi, tema hanya sebagai alat bantu untuk mencari ide. Gerakan ini bisa didapat dengan adanya musik terlebih dahulu atau gerakan dulu baru mencari musik. Media dalam eksplorasi adalah tubuh karena gerakkan dilakukan oleh tubuh. Selain tubuh, bisa menggunakan properti atau alat seperti selendang, kipas atau payung. Dengan sebuah alat, anak diminta untuk membuat gerakan menggunakan alat tersebut, yang kemudian hasilnya dicatat supaya tidak lupa. 
Kegiatan improvisasi merupakan membangun struktur tari tetapi belum sempurna atau pengayaan gerak. Setelah proses eksplorasi selesai, gerakan satu demi satu yang disusun kemudian dibuat gerakan secara holistik. Gerakan tersebut belum sempurna oleh karena itu perlu proses improvisasi. Improvisasi digunakan untuk menunjuk aktivitas yang sudah disusun namun ada kendala dalam melaksanakan aktifitas tersebut, sehingga improvisasi ini sebagai pelengkap untuk menutupi kekurangan. Kendala yang terdapat pada penciptaan karya tari adalah ketika eksplorasi sudah tersusun namun kurang sesuai dengan musik atau irama. Untuk menutupi kekurangan tersebut, gerakan tari disesuaikan dengan musik dengan membuat hitungan pada gerakan tersebut. Setelah itu gerakan dicatat beserta hitungan yang akan dijadikan suatu gerakan.

Inkubasi atau evaluasi adalah penetapan gerakan yang akan dipakai. Proses inkubasi atau evaluasi merupakan penyempurnaan dari proses eksplorasi dan improvisasi. Langkah inkubasi ini dilakukan untuk memastikan gerakan yang akan dipakai. Komposisi tari merupakan hasil atau produk tari. Komposisi merupakan hasil akhir suatu gerakan yang akan digunakan. Dalam menyusun atau mengkomposisi tari memerlukan penekanan unsur tari dengan desain, irama, motivasi dan ide. Dengan demikian unsur bagian komposisi perlu dihayati dan dimengerti. Setelah proses pembuatan tari tersebut sudah jadi, maka mulai pada langkah penampilan. Dalam pembuatan gerakan memperhatikan aspek perkembangan agama dan moral, perkembangan motorik, perkembangan kognitif, perkembangan bahasa, perkembangan sosial emosional anak dapat berkembang supaya tujuan pembelajaran tidak terabaikan. Sehingga seni tari dapat menjadi pembelajaran holistik dalam mengembangkan aspek perkembangan anak dan masa anak dapat dilalui dengan optimal karena jika salah satu aspek perkembangan anak tidak optimal maka dapat memberi dampak pada kehidupan anak masa yang akan datang. Secara detail, aspek perkembangan anak anak dapat terwujud melalui seni musik adalah sebagai berikut:

\section{Seni Tari Pada Perkembangan Agama dan Moral}

Moral merupakan perilaku yang sesuai dengan harapan, aturan, kebiasaan suatu kelompok masyarakat. Perkembangan agama meliputi kegiatan agama dan ibadah, hubungan antara manusia dengan Allah dan manusia lain. Sedangkan inti dari perkembangan moral adalah untuk membangun sebuah kerangka nilai yang mengatur perilaku pribadi. Menurut Piaget, perkembangan moral bukan berasal dari orang tua atau gen melainkan dibangun dalam 
konteks interaksi. Perilaku moral anak yang dilakukan dilembaga PAUD bukan hanya aktivitas ibadah namun juga nilai-nilai yang baik. Dalam menanamkan nilai tersebut, perlu dilakukan dengan pembiasaan karena tingkah laku anak dikendalikan oleh akibat fisik yang ditimbulkan dari perbuatannya. Oleh karena itu dengan suatu gerakan, perkembangan agama dan moral anak bisa dioptimalkan. Gerak yang mengindikasikan kegiatan pengembangan agama dan moral anak terlihat pada cara gerak yang tidak melampaui batas norma yang berlaku dan performa dalam melakukan gerakan tidak menyimpang dengan kesopanan. Dalam aktivitas pengembangan agama dan moral terletak pada penanaman nilai-nilai moral dan aktivitas tentang keagamaan. Dalam suatu pembelajaran, gerakan yang mempunyai unsur agama atau moral terlihat pada kegiatan ibadah. Misalnya, anak melakukan gerakan shalat, pembiasaan yang baik seperti membuang sampah pada tempatnya. Pada dasarnya gerakan yang dilakukan untuk mengembangkan agama dan moral anak usia dini bukan terpaku pada gerakan tarian yang diiringi irama namun gerakan-gerakan yang sebaiknya dilakukan anak sesuai dengan indikator aspek perkembangan agama dan moral.

\section{Seni Tari Pada Perkembangan Motorik}

Pembangunan fisik menggambarkan kemajuan kontrol anak atas tubuh mereka. Kemajuan tersebut ditandai dengan peningkatan keterampilan dan kompleksitas kinerja. Proses gerakan otot ini disebut perkembangan motorik. Perkembangan motorik merupakan perkembangan pengendalian gerakan jasmaniah melalui kegiatan pusat syaraf, urat syaraf dan otot terkoordinasi. Fungsi perkembangan motorik bagi perkembangan individu adalah (1) anak dapat menghibur diri dan memperoleh perasaan senang. Selain itu, bukan saja menunggu proses kematangan secara alamiah, namun juga perlu rangsangan dari lingkungan keluarga sehingga, anak berkembangan dengan baik (Saripudin, A: 2016). Contoh, anak merasa senang dengan memiliki keterampilan memainkan boneka, melempar dan menangkap bola atau memainkan alat lainnya. (2) Anak dapat beranjak dari kondisi helplessness (tidak berdaya) pada bulan pertama kehidupan menuju ke kondisi yang independence (bebas tidak bergantung). (3) Anak dapat menyesuaikan dirinya dengan lingkungan sekolah (school adjustment). Pada usia sekolah anak dapat dilatih mewarnai, menggambar, dan lainnya. (4) Anak dapat bermain atau bergaul dengan sebayanya. (5) Perkembangan fisik sangat berkaitan dengan dengan perkembangan motorik anak. Setiap permainan yang dilakukan oleh anak pasti melibatkan kemampuan kinestetik baik kasar maupun halus. Melalui permainan ini 
selain fisik tumbuh dan berkembang, namun juga merangsang pertumbuhan otak anak. Misalnya dalam permainan sepak bola tidak hanya dibutuhkan kemampuan kinestetik semata, namun pada kemampuan mengelola bola, memprediksi, melakukan kerja sama dalam bermain merupakan fungsi kerja otak. Jadi antara kegiatan yang melibatkan anggota tubuh juga melibatkan kinerja otak. Kegiatan tari dalam mengembangkan motorik dapat terbagi menjadi dua yaitu (1) mengembangkan motorik halus. Kegiatan tari bukan hanya mengembangkan motorik kasar anak namun juga motorik halus. Yang merupakan pengembangan motorik halus anak nampak pada kegiatan yang melibatkan gerakan tangan dengan memegang suatu alat atau benda. Misalnya tari yang memegang selendang atau mempermainkan selendang atau alat lain yang digunakan sebagai kreasi dalam gerak tari. Hal tersebut sebagaimana yang digambarkan pada tarian berikut: (Astuti, 2016: 18)

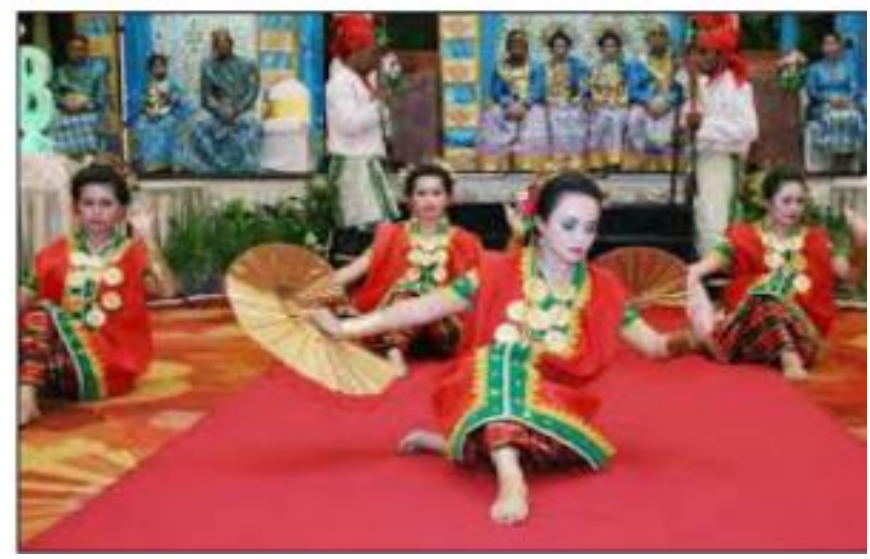

Gambar 1. Kreasi dalam gerak tari

Tari tersebut dapat melatih gerakan-gerakan motorik halus karena gerakan tersebut bertumpu pada kordinat gerakan pada tangan yaitu memegang kipas. Dengan keterampilan memegang kipas dapat memberi nuansa gambaran untuk merasakan kasar dan halus dari benda tersebut. (2) mengembangkan motorik kasar. Kegiatan tari untuk mengembangkan motorik kasar anak tampak aktivitas gerak yang menggunakan kekuatan tubuh. Untuk melatih perkembangan fisik motorik anak melalui tari dapat dilakukan dengan cara permainan. Memilih permainan tradisional Indonesia merupakan satu upaya dalam memperkaya kreativitas guru melatih motorik kasar dan halus anak. Permainan tradisional Indonesia sangat banyak jenis dan ragamnya, seperti permainan congklak, petak umpet, dan lain sebagainya. Tari yang dilakukan anak dengan melibatkan kemampuan kinestetik dengan latihan melompat 
dibutuhkan kaki yang kuat untuk menopang ragam gerak yang dapat membuat kaki anak menjadi kuat. Contoh tari untuk mengembangkan motorik kasar yaitu:

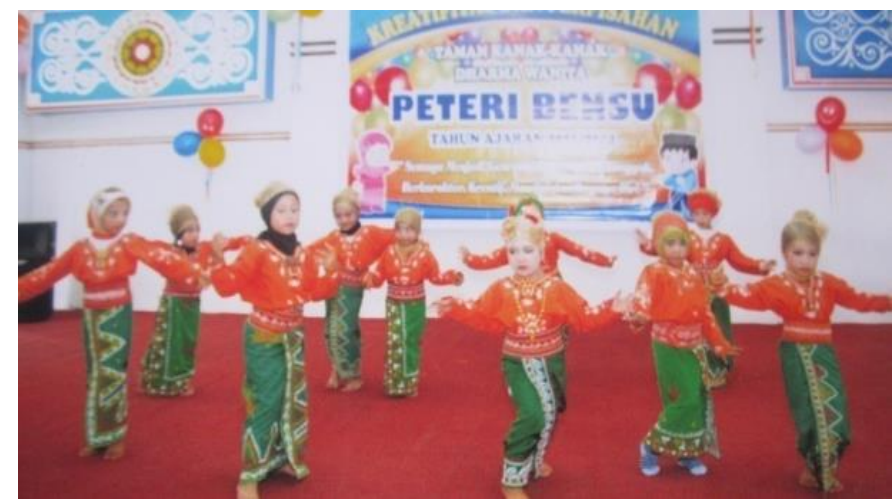

Gambar 2. Gerakan Tari

Gambar tersebut melakukan gerakan dengan berjongkok dan tumpuan kekuatan terdapat pada kaki. Jadi, dengan mengembangkan kemampuan motorik anak dengan gerakan seperti ini dapat melatih keseimbangan.

\section{Seni Tari Pada Perkembangan Kgnitif}

Perkembangan kognitif berkaitan dengan pembangunan proses berfikir. Hal ini berkaitan dengan bagaimana anak memperoleh, mengatur dan menggunakan apa yang dipelajari. Proses ini melibatkan pengembangan konseptual dan pikiran sadar, memori, pemecahan masalah, imajinasi dan kreatifitas. Perkembangan intelegensi merupakan perubahan kemampuan mental seperti belajar, memori, menalar, berfikir dan bahasa. Ini berarti dalam melakukan gerak tari dapat memfungsikan semua fungsi otak anak. Gerak tari bisa disebut dengan brain gym dipakai istilah dimensi lateralis untuk belahan otak kiri dan kanan, dimensi pemfokusan untuk bagian belakang otak (batang otak atau brainstem) dan bagian depan otak (frontal lobes), serta dimensi pemusatan untuk sistem limbik (midbrain) dan otak besar (cerebral otak). Penggunaan otak secara optimal akan mampu memberi dampak positif terhadap aktivitas belajar. Gerak tari melibatkan aktivitas fisik sehingga kebutuhan akan aktivitas fisik pada anak mempunyai peran penting karena pada masa kanakkanak pertumbuhan jasmani dan emosional serta intelektual tidak hanya ditentukan dalam bentuk pembelajaran formal semata, namun juga melalui aktivitas fisik. Hal tersebut mengantarkan anak pada pengalaman belajar walau dikemas dengan suatu permainan. Pengalaman belajar ini memberi dampak positif dalam kehidupan dan cara berfikir anak. Dus, anak terlatih untuk bersosialisasi dan mengembangkan potensi kreatif anak. 
Gerak dalam perkembangan kognitif biasanya dilakukan pada kegiatan belajar yang merupakan suatu proses usaha yang dilakukan seseorang untuk memperoleh suatu perubahan tingkah laku yang baru secara keseluruhan, sebagai hasil pengalamannya sendiri dalam interaksi dengan lingkungannya. Pembelajaran merupakan kebutuhan setiap manusia dalam melangsungkan hidupnya. Pembelajaran bukan hanya terjadi pada suatu lembaga formal namun ketika terjadi interaksi antara satu orang dengan yang lain, dan orang tersebut mendapatkan perubahan, maka secara otomatis telah terjadi suatu kegiatan pembelajaran.

Dalam pembelajaran tari dijadikan sebagai suatu pengalaman anak supaya mempunyai arti penting dalam kehidupan pada masa yang akan datang karena disebabkan belajar tari dimaknai sebuah proses perubahan dan tingkah laku anak. Dengan gerak tari pengalaman atau perkembangan belajar yang diperoleh oleh anak bisa meliputi mengeksplorasi semua kemungkinan, belajar menghargai. Misalnya antara anak dan orang tua saling menghargai, belajar segi bahasa sampai pada perilaku, belajar bekerja sama (Rachmi, 2010: 7.14-7.15). Adapun contoh gerakan dalam perkembangan kognitif sebagaimana gambar di bawah ini: (Astuti, 2016: 18).

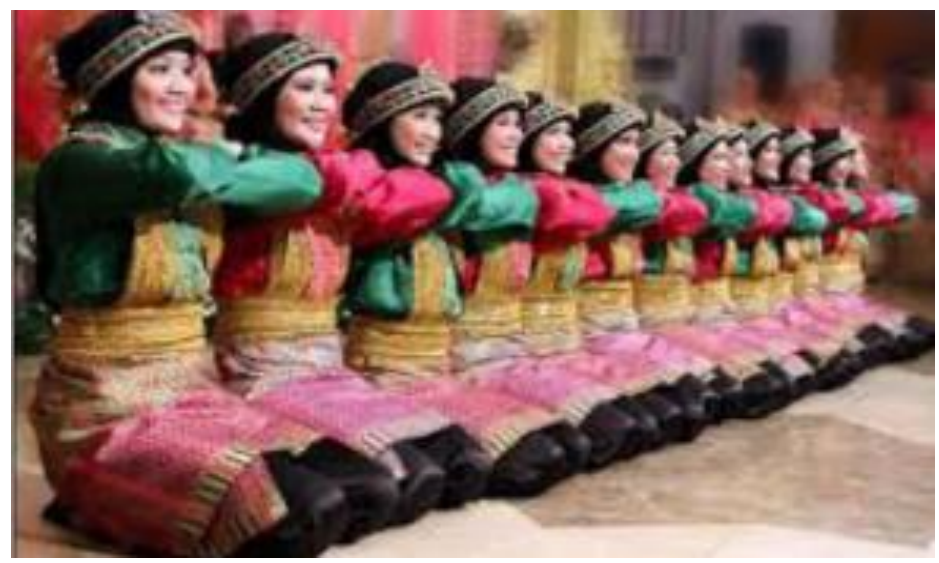

Gambar 3 : Tari dalam Perkembangan Kognitif

Aktivitas tari tersebut dilakukan dengan proses berfikir karena dilakukan dengan gerakan yang tidak sama yaitu sebagian bertepuk dengan kawan dengan posisi di bawah yang satu posisi di atas. Proses untuk berfikir dengan siapa anak akan bertepuk merupakan gerak dalam perkembangan kognitif. Gerakan tersebut anak akan mengatur apa yang dipelajari yang melibatkan memori atau ingatan. Ini berarti dalam melakukan gerak tari dapat memfungsikan semua fungsi otak anak. Tari tersebut nampak membutuhkan kerja sama antara penari satu dengan yang lainnya. Selain gerakan yang mengembangkan kognitif dengan cara belajar, bisa 
dilakukan dengan cara kerjasama dengan kelompok. Adapun gerakan interaksi yang melibatkan proses berfikir dilakukan dengan saling bersama-sama dalam membuat gerakan yang disetujui dalam satu kelompok tersebut. Gerakan tersebut sebagaimana ketika adanya gerakan suatu interaksi yang terjadi di antara dua teman akan terjadi dengan saling bertukar gerakan apa yang cocok atau yang disukai. Proses interaksi untuk memecahkan masalah dalam gerakan apa yang akan dilakukan atau gerakan apa yang akan dimainkan merupakan gerakan dalam mengembangkan kognitif anak. Dalam melakukan aktifitas gerakan belajar kelompok anak usia dini memerlukan waktu yang cukup lama. Belajar tari tidak akan berdiri sendiri namun merupakan bentuk kompleksitas dari berbagai unsur. Selain mengubah perilaku pada anak, tari juga mampu mengubah kepribadiannya. Hal tersebut diperkuat dengan pendapat Whiterington yang dikutip Rachmi, bahwa belajar merupakan perubahan dalam kepribadian yang menyatakan diri sebagai pola baru daripada reaksi serupa yang berupa sikap, kebiasaan, kepandaian atau perintah (Rachmi, 2010: 7.13). Oleh karena itu perubahan perilaku anak dalam menari tidak dapat dilihat hasilnya dalam waktu sekejap, namun memerlukan waktu.

\section{Seni Tari Pada Perkembangan Bahasa}

Bahasa merupakan cara utama di mana anak berfikir dan berkomunikasi. Anak hidup di dunia yang kompleks yang memerlukan proses canggih untuk memungkinkan berfikir dan berkomunikasi karena bahasa merupakan proses interaksi sosial dalam masyarakat di mana anak tumbuh dan belajar. Komunikasi ini bisa dilakukan dengan interaksi untuk mendorong keberanian, berdiskusi, berbagi, menjelaskan, menegaskan (Suyono, 2011: 236). Dalam mengembangkan bahasa adalah terdapat empat komponen yaitu mendengarkan, berbicara, membaca dan menulis. Ke empat komponen tersebut menjadi satu kegiatan. Dengan kemampuan mendengar, anak memahami lingkungan mereka. Mengajar anak untuk mendengarkan cara menggerakkan tangan ke atas kepala (red: contoh) akan memperbesar kesempatan untuk belajar bahasa maupun gagasan baru. Setelah anak mendengar, diberi kesempatan untuk berbicara atau menuangkan cara menggerakkan tangan ke atas.

Untuk komponen membaca, dimulai pada bangku sekolah dasar, namun banyak aktivitas lembaga PAUD dalam mengembangkan keterampilan yang mempersiapkan anak untuk belajar membaca. Dengan memberikan suasana lingkungan yang kaya dengan tulisan akan membantu anak dalam membedakan makna tulisan dan anak mulai mengerti bahwa 
tulisan itu menyampaikan sebuah pesan. Dalam melihat sebuah tarian, anak akan membaca bahwa gerakan tersebut mempunyai arti walaupun gerakan tersebut hanya diibaratkan sebagai gerak tiruan (misal gerak tari yang dilihat seperti gerakan binatang kupu-kupu).

Setelah anak mendengar, berbicara dan membaca, anak diminta untuk menulis. Aktivitas menulis anak berbeda dengan orang dewasa yaitu mulai dengan mecoret-coret dan membuat gambar. Dengan suatu tarian anak akan mengungkapkan gerak tari tersebut dengan tulisan melalui gambar. Misalnya anak diminta menggambar hewan kupu-kupu terbang, katak melompat berarti secara tersirat anak menggambar gerakan terbang dan melompat.

Kegiatan tari dalam mengembangkan keterampilan berbicara, mendengarkan, membaca dan menulis dilakukan dengan kerja sama antara anak pada kelompok kecil. Anak akan mempunyai kesempatan untuk berinteraksi satu dengan yang lain dalam cara yang lebih pribadi. Interaksi tersebut membantu memperbaiki bahasa lisan anak dengan membangun kosa kata dan menambah keterampilan melalui mendengar. Bahasa yang dikembangkan dalam kurikulum seni yaitu mendengarkan, berbicara, menulis dan membaca. Aktifitas mendengarkan pada gambar di atas terletak pada interaksi anak yang melakukan gerakan yang disertai dengan lagu, anak satu dengan yang lain saling mendengarkan untuk saling bergantian dalam bernyanyi. Aktifitas berbicara terletak pada saat mereka isi pesan dalam gerakan yang ditampilkan. Menulis dan membaca dilakukan pada proses diluar gerak tari. Dengan menulis, akan menuangkan perasaannya pada suatu lembaran berupa gambar atau tulisan yang diteruskan dengan membaca apa yang sudah digambarkan.

\section{Seni Tari Pada Perkembangan Emosi dan Sosial}

Perkembangan emosional merupakan pertumbuhan anak untuk merasakan dan mengekspresikan berbagai peningkatan emosi dengan tepat. Ekspresi tersebut merupakan respon emosional untuk diri sendiri, orang lain dan apa yang anak katakan dan lakukan. Perkembangan sosial merupakan pertambahan kemampuan anak untuk berhubungan dengan orang lain secara tepat dalam konteks kehidupan mereka. Dalam meningkatkan perkembangan emosi dan sosial melalui gerak dapat dilakukan dengan gerak atau aktivitas yang mengembangkan sosial, yaitu dalam permainan kelompok bersama. Permainan tersebut akan melibatkan gerakan pada seluruh tubuh anak. Aktivitas bemain bersama menjadikan perubahan anak dalam pola tingkah laku. Contoh gerak untuk perkembangan emosi anak: 


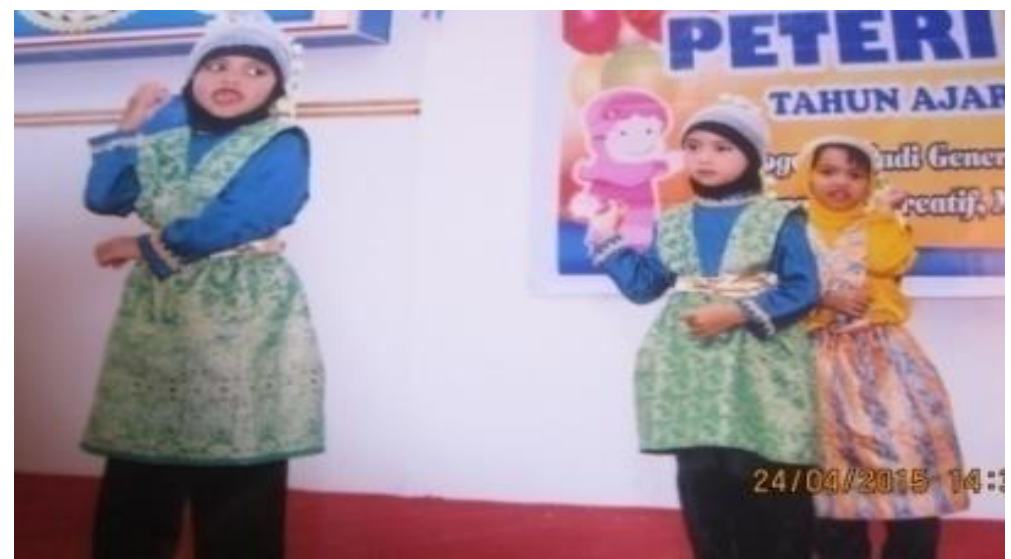

Gambar 4: Gerak Perkembangan Emosi

Sumber: TK Dharma Wanita Peteri Bensu

Gerak emosi yang sesuai dengan gambar di atas adalah bahwa terdapat anak yang sangat antusias atau semangat dalam melakukan gerak tari, itu menunjukkan bahwa anak tersebut sangat senang dalam menampilkan tariannya. Ada juga anak yang kurang senang atau biasa saja, itu menunjukkan bahwa anak tersebut senang.

Gambar tersebut mencerminkan aktivitas yang membutuhkan rasa saling menghargai dan kerja sama yang baik. Tarian ini sangat tepat bagi anak karena mengembangkan sikap dan perilaku yang sesuai dengan pertumbuhan dan perkembangan baik sosial maupun emosional.

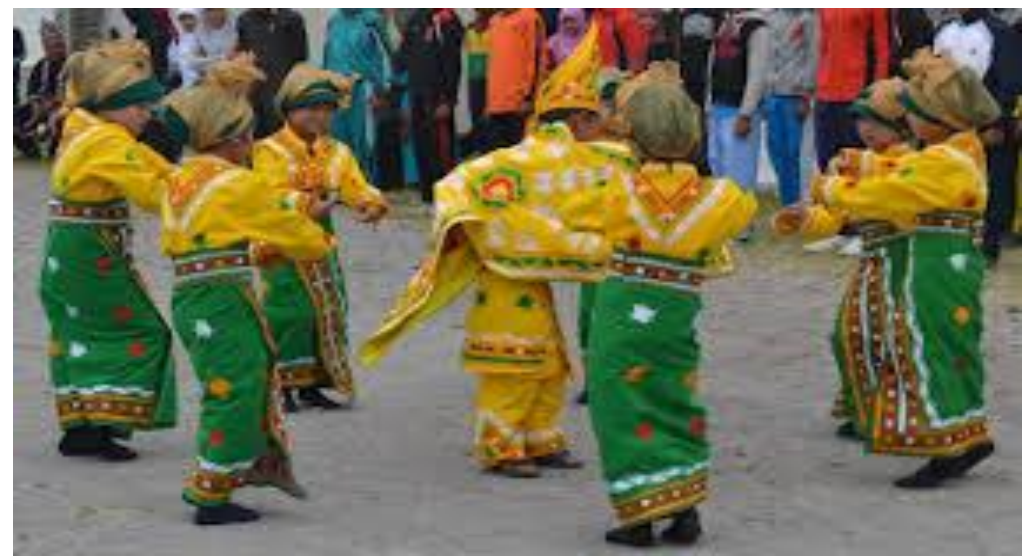

\section{Gambar 5: Gerak Pada Perkembangan Sosial (Tari Manalo)}

Penekanan dalam perkembangan sosial adalah anak terlibat dalam kegiatan belajar untuk mengambil keputusan, menunjukkan inisiatif, bekerja sama sebagai tim, menghormati orang lain dan mengembangkan pemahaman hidup bersama (Eaude, 2008: 43).

Dari aspek perkembangan anak melalui seni dapat diterapkan dengan menggunakan pendekatan terpadu, yaitu pendekatan yang dapat memberikan pemahaman secara holistik 
pada anak tentang suatu konsep atau prinsip. Cara belajar dengan pendekatan terpadu adalah pertama belajar dengan seni (learning with the arts) yaitu pengetahuan suatu subjek masalah yang dipelajari dengan bantuan suatu karya seni. Maksudnya dalam mengoptimalkan perkembangan anak usia dini secara tematik dapat disertai dengan seni. Jika pemberian materi anak dilakukan dengan menekan yang terjadi adalah hanya "angin lalu” sehingga tidak tersimpan dalam memori jangka panjang. Kedua, belajar melalui seni (learning though arts) yaitu menggali suatu subject matter melalui karya seni dengan mengungkapkan suatu konsep yang sedang dipelajari. Maksudnya, dalam proses memberikan unsur perubahan kepada anak dilakukan dengan cara mengajak langsung untuk mengungkapkan perasaan. Ketiga, belajar tentang seni (learning with arts) yaitu memahami dan mengekspresikan serta menciptakan berbagai konsep seni ke dalam karya seni. Maksudnya, mengajak anak berkomunikasi tentang objek yang dilihat, memberi stimulasi atau mengajak anak untuk merespon dapat memberi pemahaman kepada anak bahwa sesuatu yang dilihat tersebut merupakan hasil kreatifitas dan anak diminta untuk membuat hasil karya seni sesuai dengan apa yang dipikarannya tanpa meniru objek yang dilihat. Dengan begitu akan terwujud empat pilar pendidikan yaitu learning to know, learning to do, learning to be, learning to live together (Mastuhu, 2004: 134). Dari berbagai makna seni tersebut, fokus pada kajian ini adalah seni tari. Sedangkan tujuan seni tari adalah untuk menanamkan pengaruh yang bermanfaat dari kegiatan menari kreatif terhadap pembentukan kepribadian anak, bukan untuk menciptakan tarian untuk pertunjukan. Tujuan tari dalam pendidikan anak yaitu sebagai pendidikan gerak, meningkatkan kreatifitas individu, sebagai pengalaman estestis, sebagai penggabungan antar seni dan budaya serta pengalaman, sebagai media sosialisasi, media pananaman nilai budaya. Selain itu tari dilakukan untuk mengekspresikan diri, menyampaikan sejarah mereka, dan latihan olah tubuh.

\section{SIMPULAN}

Esensi utama suatu tari adalah gerak. Gerak dapat mempengaruhi segala aktifitas fisik maupun spikis. Ulasan aspek perkembangan agama dan moral yang diwujudkan melalui seni tari dapat dilakukan dengan gerakan yang terdapat indikator perilaku sesua norma yang berlaku. Jika dikaitkan dengan suatu gerakan yang diolah dengan adanya unsur tujuan tertentu dapat dilakukan dengan melakukan gerakan yang sesuai nilai kebaikan. Aspek perkembangan motorik melalui seni tari atau keindahan suatu gerakan terlihat pada dua bagian yaitu motorik 
halus dan motorik kasar. Motorik halus memfokuskan titik kordinat gerakan tangan dengan menggunakan suatu properti dalam tarian sedangkan motorik kasar bertumpu pada gerakan yang melibatkan seluruh tubuh. Perkembangan kognitif melalui seni tari terlihat pada aspek olah pikir anak yang mana setiap gerakan yang muncul pada tekanan motorik dipengaruhi oleh hasil pemikiran yang menjelajah pada bagian otak. Perkembangan bahasa melalui seni tari terlihat pada aktifitas anak dalam yang diinternalisasikan pada suatu kata-kata dari respon sebuah keindahan irama kemudian direspon oleh seluruh tubuh sehingga antara lagu yang terucap disertai dengan suatu gerakan. Perkembangan sosial emosional anak dapat berkembang melalui pendidikan seni tari nampak melalui sebuah perasaan yang dihasilkan. Kemampuan anak dalam gerak merupakan respon dari rasa yang terdapat dalam diri anak. Hal tersebut terlihat pada aktualisasi gerakan yang muncul dengan tema yang dibawa, tema yang menceritakan tentang kesedihan atau kebahagiaan menjadikan sebuah perasaan yang beragam. Perkembangan sosial tidak terlepas dari interaksi antar penari dan penonton dan antar penari itu sendiri.

\section{DAFTAR PUSTAKA}

Baharudin (2010). Pendidikan \& Psikologi Perkembangan. Yogyakarta: A-Ruzzmedia.

LesleyBritton (1992). Montessori Play and Learn: A Parents' Guide to Purposeful Play from Two to Six. New York: Crown Publishers Inc.

Nurvitasari, Marisa Deva (2016). The Aplication Of Early Childhood Development Aspects With Macca. Interactive Stack Bloock. Jurnal Pendidikan Anak Usia Dini, Edisi I

Watiniyah, Ibnu (2015). Ibu Sekuat Ibu Laki-Laki. Jakarta: Kaysa Media.

Rahman, Ulfiani (2019). Karakteristik Perkembangan Anak Usia Dini. Lentera Pendidikan, Vol.12 Nomor 1

Kusumastuti, Eny. Pendidikan Seni Tari Pada Anak Usia Dini di Taman Kanak-Kanak Tadika Puri Cabang Erlangga Semarang Sebagai Proses Alih Budaya, Harmonia, Vol.V Nomor I, hal.2-14.

Rusman (2011). Model-Model Pembelajaran: Mengembangkan Profesionalisme Guru. Jakarta: Rajagrafindo.

Uno, Hamzah B (2009). Model Pembelajaran; Menciptakan Proses Belajar Mengajar yang Kreatif dan Efektif. Jakarta: Bumi Aksara.

Supangkat, Jim,. Rizki A. Zaelani (2006), Ikatan Silang Budaya; Seni Serat Biranul Anas. tk, Art Fabrics. 
Allam, Ahmad Khalid,. Ahmad Kamaluddin Afifi, Ali Al-Azab Ali Nashr, dkk. (2005). AlQur'an dalam Keseimbangan Alam dan Kehidupan. Jakarta: Gema Insani Press.Hadzami, Syafi'i (2010). Fatwa-Fatwa Muallim Taudhihul Adillah Penjelasan Tentang Dalil-Dalil Ushul dan Akhlak. Jakarta: Kompas Gramedia.

Al-Qushayri (t.th), al-Risa>lat al-Qushayriyyah fi> 'Ilm al-Tasawaf. Beirut: Dar al-Khayr.

Al-Ghazali (t.th). Ih $\} y a$ ' 'Ulu>m al-Di>n. Kayro: Dar al-Sha'b.

Anshari, Endang Saifuddin (1992). Kuliah al-Islam. Jakarta: Raja Grafindo Persada.

Grau, Andree (2005). Eyewitness Dance. New York: DK Publshing,

Soedarsono (1992). Pengantar Apresiasi Seni. Jakarta: Balai Pustaka.

Neaum, Sally (2010). Child Development for Early Childhood Studies. Southenhay East: Learning Matters

Santrock, John W. (2007). Perkembangan Anak, edisi ke sebelas Jilid 1. Jakarta: Erlangga.

Syah Muhibin (1995), Psikologi Pendidikan Suatu Pendekatan baru, Bandung: Remaja Rosdakarya

Raco, J .R. (2010). Metode Penelitian Kualitatif: Jenis, Karakteristik dan Keunggulan. Jakarta: Grasindo.

Sugiyono (2010). Metode Penelitian Pendidikan: Pendekatan Kuantitatif, Kualitatif, dan $R$ \& $D$. Bandung: Alfabeta.

Mulyatiningsih, Endang (2011). Riset Terapan: Bidang Pendidikan \& Teknik. Yogyakarta: UNY Press.

Dewi, Resi Septiana (2012). Keanekaragaman Seni Tari Nusantara. Jakarta: Balai Pustaka.

Astuti, Fuji (2016). Pengetahuan dan Teknik Menata Tari untuk Anak Usia Dini. Jakarta: Kencana.

Saripudin, A. (2016). Peran Keluarga dalam Mengoptimalkan Perkembangan Motorik Anak Usia Dini. AWLADY: Jurnal Pendidikan Anak, 2 (1).

Rachmi, Tetty,. dkk (2010). Keterampilan Musik dan Tari. Jakarta: Universitas Terbuka.

Suyono,. Hariyanto (2011). Belajar dan Pembelajaran, Teori dan Konsep Dasar. Bandung: RosdaKarya.

Eaude, Tony (2008). Children's Spiritual, Moral, Social and Cultural Development: Primary and Early Years, Second Edition. Sounthernhay East: Learning Matters.

Mastuhu (2004). Menata Ulang Pemikiran Sistem Pendidikan Nasional dalam Abad 21. Yogyakarta: Safiria Insania Press bekerja sama dengan MSI UII. 